Tarlok Singh'

\title{
Sustainability of Current Account Deficits in the OECD Countries: Evidence from Panel Data Estimators
}

\author{
${ }^{1}$ Department of Accounting, Finance and Economics, Griffith Business School, Griffith University, Nathan Campus, 170 Kessels \\ Road, Brisbane, Queensland-4111, Australia., E-mail: Tarlok.Singh@griffith.edu.au
}

\begin{abstract}
:
This study estimates the intertemporal model for the relationship between imports and exports and examines the sustainability of CADs and validity of IBC for a comprehensive set of 24 OECD countries. The balanced panel data model is estimated using several single-equation and system estimators to assess the robustness of results across methodologies and test statistics. The study finds that the numerical magnitude of the slope parameter of imports is close to unity consistently across estimators. The standard panel data estimators provide consistent support for the sustainability of CADs and validity of IBC. The optimal FMOLS and DOLS estimators cross-validate the evidence and reinforce the sustainability of CADs. The residual-based single-equation and the VAR-based system cointegration estimators provide consistent support for the long-run equilibrium relationship between imports and exports. The support for the sustainability of CADs suggests that the current account deficits are only short-run phenomena and are balanced by future surpluses. The macroeconomic stabilisation strategies seem to have been effective in correcting the market failures and maintaining the steadystate equilibrium relationship between the inflow and outflow of resources.
\end{abstract}

Keywords: imports, exports, current account deficits, intertemporal budget constraint, panel cointegration DOI: 10.1515/gej-2017-0069

\section{Introduction}

The sustainability of current account deficits and the solvency of external debt remain central to the stability of financial markets and the formulation of macro-management strategies. The recurrent episodes of economic and financial crises have deepened concerns and rejuvenated the need for constant vigilance on external account imbalances. The short-run and transitory current account deficits (CADs) reflect the reallocation of world capital resources to most productive avenues and, as such, are commonly not a cause of concern. In contrast, the long-run and persistent CADs and the resultant accumulations of external debt potentially lead to (i) speculative attacks on the external value of domestic currency, (ii) intergenerational transfer of international debt burdens, and the (iii) occurrence of financial calamities and economic upheavals. The foreign exchange reserves accumulated over time from current account surpluses could help circumvent the depreciation of exchange rate and ignition of balance of payments crises. A country with inadequate or no reserves can borrow resources from international financial markets to defend its exchange rate and prevent the default on the repayment of its external debt. The ability to borrow abroad generally will also allow a country to borrow at lower interest rates, and with less pressure on exchange rate and therefore on inflation, than if it was financially closed (Obstfeld 2012). The ability of a country to borrow internationally depends on the existing magnitude of its external debt. The risk-averse international investors are unlikely to lend if a country runs large and persistent CADs, and is beset with the syndrome of over borrowing and implied likelihood of default on the repayment of its foreign debt. If the international capital markets are informationally efficient, then risk premium attached to the borrowing country's debt will increase in tandem with the magnitude of external debt, and the altitude of such premium will reflect the likelihood of default. The lenders with asymmetric and imperfect information may though find it difficult to attach an accurate risk premium on their international credit.

The magnitude of CAD serves as a constraint on the ability of the borrower to borrow and the willingness of the lender to lend. A country can borrow resources from the world capital markets so long as its CADs and external debt are sustainable. The sustainability of external position could be determined in terms of the ratio of CAD to gross domestic product (GDP) (Milesi-Ferretti and Razin 1996; Freund 2005) and/or the ratio of net 
international debt to GDP (Krugman 1988; Roubini and Wachtel 1998; Edwards 2002). The CAD becomes unsustainable and the adjustment process typically begins when it hovers around 5\% of the GDP (Milesi-Ferretti and Razin 1996; Freund 2005). It takes three to four years to resolve, and involves slowing income growth and a significant real exchange rate depreciation (Freund 2005). While the ratio-based norms are informative of external position, these tend to ignore the heterogeneity in economic conditions across countries and over time. Also, the threshold levels of the suggested ratios are only the best approximations, rather than precise plimsoll lines, for the sustainability of external position. There are significant cross-country variations not only in the size of estimated thresholds, but also in the estimated speed of adjustment once the countries cross their current account deficit or surplus thresholds (Clarida, Goretti, and Taylor 2007).

The intertemporal optimization approach to current account takes a long-term perspective and instead determines the sustainability of CADs in terms of the validity of intertemporal budget constraint; see Obstfeld and Rogoff $(1996,2007)$ for the surveys. The CAD is sustainable and intertemporal budget constraint (IBC) is valid when present value of foreign debt outstanding at the end of time $t$ is equal to the sum of present values of all future net trade surpluses or net output (aggregate output minus consumption, investment and government spending). The cointegration estimators developed since the paradigm shift in econometric methodology in the late-1980s are useful to assess the time-series properties of the model series and statistically test the sustainability of CADs and validity of IBC. The CAD is statistically sustainable when it is mean-reverting and stationary (Trehan and Walsh 1991; Taylor 2002). The stationarity of CAD implies that the imports (outflow of resources) and exports (inflow of resources) are cointegrated and bound in a long-term equilibrium relationship. The studies using the intertemporal optimization approach to current account provide a mixed and inconclusive evidence in that (i) some studies support the stationarity of current account and suggest the sustainability of CADs and validity of IBC (Trehan and Walsh 1991; Husted 1992; Liu and Tanner 1996; Bergin and Sheffrin 2000; Wu 2000; Wu, Chen, and Lee 2001; Arize 2002; Irandoust and Ericsson 2004; Matsubayashi 2005; Chu et al. 2007; Christopoulos and León-Ledesma 2010; Durdu, Mendoza, and Terrones 2013), (ii) some support the non-stationarity of current account and show the unsustainability of CADs and violation of IBC (Otto 1992; Wickens and Uctum 1993; Liu and Tanner 1996; Wu, Fountas, and Chen 1996) and (iii) yet some others yield mixed results (Sawada 1994; Raybaudi, Sola, and Spagnolo 2004; Holmes 2006; Konya 2009; Camarero, Carrion-i-Silvestre, and Tamarit 2013; Bajo-Rubio, Díaz-Roldán, and Esteve 2014; Lanzafame 2014; Chen and Xie 2015).

This study estimates the intertemporal model and examines the sustainability of CADs and validity of IBC for a comprehensive set of 24 OECD countries. The time-series models used in previous studies to test the nonstationarity of current account and/or non-cointegration between trade flows tend to have low power due to the small sample space. The statistical inference drawn from these models with low power becomes weak and dubious. The panel data models with increased sample size have more power and, as such, are a useful alternative to time-series models. The panel data models alleviate the model mis-specification bias in that the individualspecific effects allow for unobservable heterogeneous factors across different cross-sectional units (such as economic growth, country size, and government policy reactions), while the time-specific effects account for the time-varying factors (such as business cycles). The reliance on single or select estimators to estimate the model could lead to biased assessment in terms of both statistical inference and magnitudes of long-run parameters. The study follows panel data approach and uses several single-equation and system estimators to estimate the model and assess the robustness of results across methodologies and test statistics. The remainder of the study is structured as follows. Section 2 presents the model. Section 3 discusses the empirical results. Section 4 sums up the conclusions.

\section{The Model}

Consider a small open economy where the forward-looking optimizing agents can borrow and lend resources in international financial markets at the world rate of interest and maximize their lifetime utility function subject to budget constraint (Husted 1992; Konya 2009). The aggregate resources are equal to aggregate expenditure at the end of a discrete time $t$ such that the current-period budget constraint with no government can be represented as

$$
Y_{t}+\left(B_{t}-B_{t-1}\right)=C_{t}+I_{t}+r_{t} B_{t-1}
$$

The $C_{t}$ denotes consumption, $I_{t}$ investment, $Y_{t}$ aggregate output and $r_{t}$ the time-varying world rate of interest. The $B_{t}$ measures net international borrowing, and the CA at time t could be in surplus, $C A_{t}=\Delta B_{t}=$ $\left(B_{t}-B_{t-1}\right)>0$, or deficit, $C A_{t}=\Delta B_{t}=\left(B_{t}-B_{t-1}\right)<0$. The budget constraint eq. (1) must be satisfied for every time period, and it can be iterated forward in time to form the IBC. 


$$
B_{t}=-\mathrm{TB}_{\mathrm{t}}+\left(1+\mathrm{r}_{\mathrm{t}}\right) \mathrm{B}_{\mathrm{t}-1}
$$

The $\left(1+r_{t}\right) B_{t-1}$ is the initial level of external debt of the economy and $T B_{t}=\left(X_{t}-M_{t}\right)=\left(Y_{t}-C_{t}-I_{t}\right)$ is the trade balance; where $X_{t}$ denotes exports and $M_{t}$ imports at time $t$. By recursively solving the difference eq. (2), the forward-looking solution for external borrowings can be obtained as

$$
\begin{gathered}
B_{t+1}=-T_{t+1}+\left(1+r_{t+1}\right) B_{t} \\
B_{t+2}=-T B_{t+2}-\left(1+r_{t+2}\right) T_{t+1}+\left(1+r_{t+1}\right)\left(1+r_{t+2}\right) B_{t} \\
B_{t+3}=-T B_{t+3}-\left(1+r_{t+3}\right) T B_{t+2}-\left(1+r_{t+2}\right)\left(1+r_{t+3}\right) T B_{t+1}+\left(1+r_{t+1}\right)\left(1+r_{t+2}\right)\left(1+r_{t+3}\right) B_{t}
\end{gathered}
$$

The process of motion iterated successively for $n$ periods ahead becomes

$$
\begin{gathered}
B_{t+n}=-T_{t+n}-\left(1+r_{t+n}\right) T_{t+n-1}-\ldots-\left(1+r_{t+2}\right) \ldots\left(1+r_{t+n-1}\right)\left(1+r_{t+n}\right) T_{t+1} \\
+\ldots+\left(1+r_{t+1}\right) \ldots\left(1+r_{t+n-1}\right)\left(1+r_{t+n}\right) B_{t} \\
B_{t}=\frac{B_{t+n}}{\left(1+r_{t+1}\right) \ldots\left(1+r_{t+n-1}\right)\left(1+r_{t+n}\right)}+\frac{T_{t+n}}{\left(1+r_{t+1}\right) \ldots\left(1+r_{t+n-1}\right)\left(1+r_{t+n}\right)}+ \\
\frac{\left(1+r_{t+n}\right) T_{t+n-1}}{\left(1+r_{t+1}\right) \ldots\left(1+r_{t+n-1}\right)\left(1+r_{t+n}\right)}+\ldots+\frac{\left(1+r_{t+2}\right) \ldots\left(1+r_{t+n-1}\right)\left(1+r_{t+n}\right) T_{t+1}}{\left(1+r_{t+1}\right) \ldots\left(1+r_{t+n-1}\right)\left(1+r_{t+n}\right)} \\
B_{t}=\frac{T B_{t+n}}{\left(1+r_{t+1}\right) \ldots\left(1+r_{t+n-1}\right)\left(1+r_{t+n}\right)}+\frac{T B_{t+n-1}}{\left(1+r_{t+1}\right) \ldots\left(1+r_{t+n-1}\right)}+\ldots+\frac{T B_{t+1}}{\left(1+r_{t+1}\right)}+\frac{B_{t+n}}{\left(1+r_{t+1}\right) \ldots\left(1+r_{t+n-1}\right)\left(1+r_{t+n}\right)}
\end{gathered}
$$

The limiting dynamics of the process of motion iterated forward for an infinite-time horizon yield

$$
\mathrm{B}_{\mathrm{t}}=\sum_{\mathrm{i}=1}^{\infty} \beta_{\mathrm{i}} \mathrm{TB}_{\mathrm{t}+\mathrm{i}}+\lim _{\mathrm{n} \rightarrow \infty} \beta_{\mathrm{n}} \mathrm{B}_{\mathrm{t}+\mathrm{n}} \text { where } \beta_{\mathrm{i}}=\prod_{j=1}^{\mathrm{i}}\left(\frac{1}{1+\mathrm{r}_{\mathrm{t}+\mathrm{j}}}\right)
$$

The transversality condition $\lim _{n \rightarrow \infty} \beta_{n} B_{t+n}=0$ on external borrowing must be satisfied for a country to be solvent and have zero-Ponzi financing and no roll-overs of external deficits (Husted 1992; Konya 2009). The present value of foreign debt outstanding at the end of time t should be equal to the sum of the discounted values of all future net trade surpluses. The country would be beset with debt overhang and, thus, be 'bubble financing' its debt repayments using Ponzi schemes, if $\left(B_{t}-\sum_{i=1}^{\infty} \beta_{i} T B_{t+i}\right)=\lim \beta_{\dot{n}} B_{t+n}>0$ and the stock of foreign debt is greater than the future payments. In contrast, the country would be making Pareto-inferior decisions in that welfare could be raised by lending less, if $\left(B_{t}-\sum_{i=1}^{\infty} \beta_{i} T B_{t+i}\right)=\lim \beta_{n} B_{t+n}>0$ (Husted 1992). Some studies use expectation operator and iterate model eq. (1) forward to arrive at a stochastic rendition of the model. This approach is not strictly tenable given that model eq. (1) is an accounting identity and it must hold for all realizations of the variables involved and not just the 'expected' or 'average' realizations (Hakkio and Rush 1991; Husted 1992). Using $\mathrm{TB}_{t}=\left(\mathrm{X}_{t}-\mathrm{M}_{t}\right)=\left(\mathrm{Y}_{\mathrm{t}}-\mathrm{C}_{t}-\mathrm{I}_{\mathrm{t}}\right)$, eq. (2) can be represented as

$$
\left(X_{t}-M_{t}\right)=-B_{t}+\left(1+r_{t}\right) B_{t-1}
$$

The world rate of interest, $r_{t}$, in eq. (3) is assumed to be stationary with unconditional mean, $r$, so that $r_{t}=r+\mu_{t}$ and $E\left(r_{t}\right)=E(r)+E\left(\mu_{t}\right)=r$; where $E\left(\mu_{t}\right)=0$ are random disturbances with zero-mean. By adding and subtracting $\mathrm{rB}_{t-1}$, and after some algebraic manipulations, eq. (3) can be expressed as

$$
\begin{gathered}
X_{t}+B_{t}=M_{t}+\left(r_{t}-r\right) B_{t-1}+(1+r) B_{t-1} \\
B_{t}=Z_{t}-X_{t}+(1+r) B_{t-1} ; \quad \text { where } Z_{t}=M_{t}+\left(r_{t}-r\right) B_{t-1}
\end{gathered}
$$


The iterative dynamics of foreign borrowings in eq. (4) can be evolved as

$$
\begin{gathered}
B_{t+1}=Z_{t+1}-X_{t+1}+(1+r) B_{t} \\
B_{t+2}=Z_{t+2}-X_{t+2}+(1+r)\left(Z_{t+1}-X_{t+1}\right)+(1+r)^{2} B_{t} \\
B_{t+3}=Z_{t+3}-X_{t+3}+(1+r)\left(Z_{t+2}-X_{t+2}\right)+(1+r)^{2}\left(Z_{t+1}-X_{t+1}\right)+(1+r)^{3} B_{t} \\
B_{t+3}=Z_{t+3}-X_{t+3}+(1+r)\left(Z_{t+2}-X_{t+2}\right)+(1+r)^{2}\left(Z_{t+1}-X_{t+1}\right)+(1+r)^{3}\left(Z_{t}-X_{t}\right)+(1+r)^{4} B_{t-1}
\end{gathered}
$$

The forward iterations and recursive substitutions for $\mathrm{n}$ periods yield

$$
\begin{aligned}
& B_{t+n}=Z_{t+n}-X_{t+n}+(1+r)\left(Z_{t+n-1}-X_{t+n-1}\right)+(1+r)^{2}\left(Z_{t+n-2}-X_{t+n-2}\right)+\ldots+(1+r)^{5}\left(Z_{t}-X_{t}\right)+(1+r)^{n+1} B_{t-1} \\
& \mathrm{~B}_{\mathrm{t}+\mathrm{n}}=\sum_{j=0}^{n}(1+r)^{n-j}\left(\mathrm{Z}_{\mathrm{t}+\mathrm{j}}-\mathrm{X}_{\mathrm{t}+\mathrm{j}}\right)+(1+\mathrm{r})^{\mathrm{n}+1} \mathrm{~B}_{\mathrm{t}-1} \\
& (1+r)^{n+1} B_{t-1}=B_{t+n}-\sum_{j=0}^{n}(1+r)^{n-j}\left(Z_{t+j}-X_{t+j}\right) \\
& B_{t-1}=\frac{B_{t+n}}{(1+r)^{n+1}}-\frac{\sum_{j=0}^{n}(1+r)^{n-j}\left(Z_{t+j}-X_{t+j}\right)}{(1+r)^{n+1}} \\
& B_{t-1}=\frac{B_{t+n}}{(1+r)^{n+1}}-\frac{\sum_{j=0}^{n}\left(Z_{t+j}-X_{t+j}\right)}{(1+r)^{1+j}} \\
& B_{t-1}=\sum_{j=0}^{n} \delta^{1+j}\left(X_{t+j}-Z_{t+j}\right)+\delta^{n+1} B_{t+n} ; \text { where } \delta=\frac{1}{(1+r)}
\end{aligned}
$$

The above process iterated forward for an infinite-time horizon with limit $\mathrm{n} \rightarrow \infty$ becomes

$$
\begin{gathered}
\mathrm{B}_{\mathrm{t}-1}=\sum_{\mathrm{j}=0}^{\infty} \delta^{1+j}\left(\mathrm{X}_{\mathrm{t}+\mathrm{j}}-\mathrm{Z}_{\mathrm{t}+\mathrm{j}}\right)+\lim _{n \rightarrow \infty} \delta^{\mathrm{n}+1} \mathrm{~B}_{\mathrm{t}+\mathrm{n}} \\
\mathrm{B}_{\mathrm{t}-1}=\delta\left(\mathrm{X}_{\mathrm{t}}-\mathrm{Z}_{\mathrm{t}}\right)+\delta^{2}\left(\mathrm{X}_{\mathrm{t}+1}-\mathrm{Z}_{\mathrm{t}+1}\right)+\delta^{3}\left(\mathrm{X}_{\mathrm{t}+2}-\mathrm{Z}_{\mathrm{t}+2}\right)+\delta^{4}\left(\mathrm{X}_{\mathrm{t}+3}-\mathrm{Z}_{\mathrm{t}+3}\right)+\ldots+\lim _{\mathrm{n} \rightarrow \infty} \delta^{\mathrm{n}+1} \mathrm{~B}_{\mathrm{t}+\mathrm{n}} \\
\mathrm{B}_{\mathrm{t}-1}=\delta\left(\mathrm{X}_{\mathrm{t}}-\mathrm{Z}_{\mathrm{t}}\right)+\delta^{2}\left(\delta \mathrm{X}_{\mathrm{t}+1}-\delta \mathrm{Z}_{\mathrm{t}+1}\right)+\delta^{2}\left(\mathrm{X}_{\mathrm{t}}-\mathrm{Z}_{\mathrm{t}}\right) \\
+\delta^{3}\left(\delta \mathrm{X}_{\mathrm{t}+2}-\delta \mathrm{Z}_{\mathrm{t}+2}\right)+\delta^{3}\left(\mathrm{X}_{\mathrm{t}+1}-\mathrm{Z}_{\mathrm{t}+1}\right) \\
+\delta^{4}\left(\delta \mathrm{X}_{\mathrm{t}+3}-\delta \mathrm{Z}_{\mathrm{t}+3}\right)+\delta^{4}\left(\mathrm{X}_{\mathrm{t}+2}-\mathrm{Z}_{\mathrm{t}+2}\right)+\ldots+\lim _{\mathrm{n} \rightarrow \infty} \delta^{\mathrm{n}+1} \mathrm{~B}_{\mathrm{t}+\mathrm{n}} \\
\mathrm{B}_{\mathrm{t}-1}=\delta\left(\mathrm{X}_{\mathrm{t}}-\mathrm{Z}_{\mathrm{t}}\right)+\delta \sum_{\mathrm{j}=1}^{\infty} \delta^{\mathrm{j}}\left(\delta \mathrm{X}_{\mathrm{t}+\mathrm{j}}-\delta \mathrm{Z}_{\mathrm{t}+\mathrm{j}}\right)+\delta \sum_{\mathrm{j}=0}^{\infty} \delta^{1+\mathrm{j}}\left(\mathrm{X}_{\mathrm{t}+\mathrm{j}}-\mathrm{Z}_{\mathrm{t}+\mathrm{j}}\right)+\ldots+\lim _{\mathrm{n} \rightarrow \infty} \delta^{\mathrm{n}+1} \mathrm{~B}_{\mathrm{t}+\mathrm{n}}
\end{gathered}
$$

Solving eq. (5) for

$$
\sum_{j=0}^{\infty} \delta^{1+j}\left(X_{t+j}-Z_{t+j}\right)=B_{t-1}-\lim _{n \rightarrow \infty} \delta^{n+1} B_{t+n}
$$

and then substituting the resulting transform eq. (7) into eq. (6) yields

$$
\mathrm{B}_{\mathrm{t}-1}=\delta\left(\mathrm{X}_{\mathrm{t}}-\mathrm{Z}_{\mathrm{t}}\right)+\delta \sum_{\mathrm{j}=1}^{\infty} \delta^{j}\left(\delta \mathrm{X}_{\mathrm{t}+\mathrm{j}}-\delta \mathrm{Z}_{\mathrm{t}+\mathrm{j}}\right)+\delta\left[\mathrm{B}_{\mathrm{t}-1}-\lim _{\mathrm{n} \rightarrow \infty} \delta^{\mathrm{n}+1} \mathrm{~B}_{\mathrm{t}+\mathrm{n}}\right]+\ldots+\lim _{\mathrm{n} \rightarrow \infty} \delta^{\mathrm{n}+1} \mathrm{~B}_{\mathrm{t}+\mathrm{n}}
$$




$$
\begin{gathered}
\mathrm{B}_{\mathrm{t}-1}=\delta\left(\mathrm{X}_{\mathrm{t}}-\mathrm{Z}_{\mathrm{t}}\right)+\delta \sum_{\mathrm{j}=1}^{\infty} \delta^{\mathrm{i}}\left(\delta \mathrm{X}_{\mathrm{t}+\mathrm{j}}-\delta \mathrm{Z}_{\mathrm{t}+\mathrm{j}}\right)+\delta \mathrm{B}_{\mathrm{t}-1}+(1-\delta) \lim _{\mathrm{n} \rightarrow \infty} \delta^{\mathrm{n}+1} \mathrm{~B}_{\mathrm{t}+\mathrm{n}} \\
\mathrm{B}_{\mathrm{t}-1}-\delta \mathrm{B}_{\mathrm{t}-1}=\delta\left[\left(\mathrm{X}_{\mathrm{t}}-\mathrm{Z}_{\mathrm{t}}\right)+\sum_{j=1}^{\infty} \delta^{i}\left(\delta \mathrm{X}_{\mathrm{t}+\mathrm{j}}-\delta \mathrm{Z}_{\mathrm{t}+\mathrm{j}}\right)+\frac{(1-\delta)}{\delta} \lim _{\mathrm{n} \rightarrow \infty} \delta^{\mathrm{n}+1} \mathrm{~B}_{\mathrm{t}+\mathrm{n}}\right] \\
\left(\frac{1-}{\delta}\right) \mathrm{B}_{\mathrm{t}-1}+\mathrm{Z}_{\mathrm{t}}=\mathrm{X}_{\mathrm{t}}+\sum_{\mathrm{j}=1}^{\infty} \delta^{\mathrm{j}}\left(\delta \mathrm{X}_{\mathrm{t}+\mathrm{j}}-\delta \mathrm{Z}_{\mathrm{t}+\mathrm{j}}\right)+\frac{(1-\delta)}{\delta} \lim _{\mathrm{n} \rightarrow \infty} \delta^{\mathrm{n}+1} \mathrm{~B}_{\mathrm{t}+\mathrm{n}} \\
\mathrm{r} \mathrm{B}_{\mathrm{t}-1}+\mathrm{Z}_{\mathrm{t}}=\mathrm{X}_{\mathrm{t}}+\sum_{\mathrm{j}=1}^{\infty} \delta^{\mathrm{j}}\left(\delta \mathrm{X}_{\mathrm{t}+\mathrm{j}}-\delta \mathrm{Z}_{\mathrm{t}+\mathrm{j}}\right)+\mathrm{r} \lim _{\mathrm{n} \rightarrow \infty} \delta^{\mathrm{n}+1} \mathrm{~B}_{\mathrm{t}+\mathrm{n}} \mid \because \delta=\frac{1}{(1+\mathrm{r})} \Rightarrow \mathrm{r}=\left(\frac{1-}{\delta}\right)
\end{gathered}
$$

The stochastic variables $X_{t} \sim \mathrm{I}(1)$ and $Z_{t} \sim \mathrm{I}(1)$ are assumed to be random walks with drifts so that the data generating processes (DGP) follow the AR(1) representations given by

$$
\begin{aligned}
& \mathrm{X}_{\mathrm{t}}=\alpha_{1}+\mathrm{X}_{\mathrm{t}-1}+\varepsilon_{1 \mathrm{t}} ; \Rightarrow \Delta \mathrm{X}_{\mathrm{t}}=\alpha_{1}+\varepsilon_{1 \mathrm{t}} \Rightarrow \Delta \mathrm{X}_{\mathrm{t}+\mathrm{j}}=\alpha_{1}+\varepsilon_{1 \mathrm{t}+\mathrm{j}} \\
& \mathrm{Z}_{\mathrm{t}}=\alpha_{2}+\mathrm{Z}_{\mathrm{t}-1}+\varepsilon_{2 \mathrm{t}} ; \Rightarrow \Delta \mathrm{Z}_{\mathrm{t}}=\alpha_{2}+\varepsilon_{2 \mathrm{t}} \Rightarrow \Delta \mathrm{Z}_{\mathrm{t}+\mathrm{j}}=\alpha_{2}+\varepsilon_{2 \mathrm{t}+\mathrm{j}}
\end{aligned}
$$

The $\alpha_{\mathrm{j}} ; \forall \mathrm{j} \in\{1,2\}$ are the drift parameters (possibly equal to zero) and $\varepsilon_{j t} \sim I(0) ; \forall j \in\{1,2\}$ are the Gaussian residual terms. By substituting eqs (9) and (10) into eq. (8) and assuming that $\delta$ is a bounded set such that $0<\delta<1$, the deterministic eq. (8) can be transformed into stochastic form as

$$
\begin{gathered}
r B_{t-1}+Z_{t}=X_{t}+\sum_{j=1}^{\infty} \delta^{j}\left(\alpha_{1}+\varepsilon_{1 t+j}-\alpha_{2}-\varepsilon_{2 t+j}\right)+r \lim _{n \rightarrow \infty} \delta^{n+1} B_{t+n} \\
r B_{t-1}+Z_{t}=X_{t}+\sum_{j=1}^{\infty} \delta^{j}\left(\alpha_{1}-\alpha_{2}\right)+\sum_{j=1}^{\infty} \delta^{j}\left(\varepsilon_{1 t+j}-\varepsilon_{2 t+j}\right)+r \lim _{n \rightarrow \infty} \delta^{n+1} B_{t+n}
\end{gathered}
$$

Since $\sum_{j=1}^{\infty} \delta^{j}=\sum_{j=1}^{\infty}\left(\frac{1}{1+r}\right)^{j}=\frac{1}{r}$, eq. (11) becomes

$$
r B_{t-1}+Z_{t}=X_{t}+\left(\frac{\alpha_{1}-\alpha_{2}}{r}\right)+\sum_{j=1}^{\infty} \delta^{j}\left(\varepsilon_{1 t+j}-\varepsilon_{2 t+j}\right)+r \lim _{n \rightarrow \infty} \delta^{n+1} B_{t+n}
$$

$$
\begin{aligned}
& M_{t}+r_{t} B_{t-1}=X_{t}+\left(\frac{\alpha_{1}-\alpha_{2}}{r}\right)+\sum_{j=1}^{\infty} \delta^{j}\left(\varepsilon_{1 t+j}-\varepsilon_{2 t+j}\right)+r \lim _{n \rightarrow \infty} \delta^{n+1} B_{t+n} \quad \begin{array}{l}
\because Z_{t}=M_{t}+\left(r_{t}-r\right) B_{t-1} \\
\therefore Z_{t}+r B_{t-1}=M_{t}+r_{t} B_{t-1}
\end{array} \\
& X_{t}=M_{t}+r_{t} B_{t-1}+\left(\frac{\alpha_{2}-a_{1}}{r}\right)+\sum_{j=1}^{\infty} \delta^{j}\left(\varepsilon_{2 t+j}-\varepsilon_{1 t+j}\right)-r \lim _{n \rightarrow \infty} \delta^{n+1} B_{t+n}
\end{aligned}
$$

The transversality condition for intertemporal solvency with no debt bubbles and implied no binding to run Ponzi games to finance the repayments of debt requires that the discounted values of state variables must converge to zero as time tends to approach infinity. The transversality condition determines the equilibrium path of external imbalances and limits the borrowing over an infinite-time horizon to zero so that $r \lim _{n \rightarrow \infty} \delta^{n+1} B_{t+n}=0$ (see Konya 2009). By imposing no-Ponzi games limiting condition and by letting import index $\mathrm{MM}_{\mathrm{t}}=\mathrm{M}_{\mathrm{t}}+\mathrm{r}_{\mathrm{t}} \mathrm{B}_{\mathrm{t}-1}, \alpha=\left(\alpha_{2}-\alpha_{1}\right) / \mathrm{r}$ and $\varepsilon_{\mathrm{t}}=\sum_{\mathrm{j}=1}^{\infty} \delta^{\mathrm{j}}\left(\varepsilon_{2 \mathrm{t}+\mathrm{j}}-\varepsilon_{1 \mathrm{t}+\mathrm{j}}\right)$, the tractable rendition of eq. (12) can be represented as

$$
\mathrm{X}_{\mathrm{t}}=\alpha+\beta \mathrm{MM}_{\mathrm{t}}+\varepsilon_{\mathrm{t}}
$$

The CAD in model eq. (13) is sustainable and IBC is valid when the long-run relationship between imports (outflow of resources) and exports (inflow of resources) converges towards equilibrium so that $\varepsilon_{\mathrm{t}} \sim \mathrm{I}(0)$ (Husted 1992). The CAD becomes unsustainable and IBC invalid when $\varepsilon_{t} \sim \mathrm{I}(1)$ and, in such case, the economy is beset with the possibilities of default on the repayment of its external debt. The presence of cointegration is a necessary, but not a sufficient condition for an economy to satisfy its IBC. A more stringent (sufficient) condition for the sustainability of current account and solvency of IBC requires that the cointegrating vector should be 
$[1,-1]$ when trade flows are measured as a ratio to GDP. By letting $\alpha=0, \beta=1$ and $\varepsilon_{\mathrm{t}} \sim \mathrm{I}(0)$, model eq. (13) can be expressed as

$$
\mathrm{CA}_{\mathrm{t}}=\left(\mathrm{X}_{\mathrm{t}}-\mathrm{MM}_{\mathrm{t}}\right)=(1,-1)\left(\begin{array}{l}
\mathrm{X}_{\mathrm{t}} \\
\mathrm{MM}_{\mathrm{t}}
\end{array}\right)=\varepsilon_{\mathrm{t}} \sim \mathrm{I}(0)
$$

If exports are cointegrated with imports, but the cointegration coefficient, $\beta$, is statistically less than one, then the economy fails to satisfy its budget constraint. Model eq. (13) in a cross-sectional settling can be specified as

$$
\mathrm{X}_{\mathrm{it}}=\alpha+\beta \mathrm{MM}_{\mathrm{it}}+\varepsilon_{\mathrm{it}}, \quad \mathrm{i} \in[1,2, \ldots, \mathrm{N}], \mathrm{t} \in[1, \ldots, \mathrm{T}]
$$

Model eq. (15) is estimated on annual data with a constant time space, $\mathrm{T} \in\{1970,1971, \ldots, 2006\}$, for a comprehensive set of 24 OECD countries: Australia, Austria, Belgium, Canada, Denmark, Finland, France, Germany, Greece, Iceland, Ireland, Italy, Japan, Luxembourg, the Netherlands, New Zealand, Norway, Portugal, Spain, Sweden, Switzerland, Turkey, the United Kingdom, and the United States. The exports, X, and imports, MM, of goods and services are measured as percentages of gross domestic product (GDP), all at current prices. All of the data are sourced from the World Development Indicators (Online), The World Bank. The current account comprises trade balance (exports net of imports of goods and services), net factor income from abroad, and the net current transfers. A country with accumulated CADs needs to pay interest on its foreign debt and these interest payments appear in the net factor income balance. The exports and imports of goods and services are commonly a major component of current account. Husted (1992) tests for cointegration between nominal exports and imports as well as between real exports and imports, as the theory can be expressed in either nominal or real terms. ${ }^{1}$ Husted (1992) finds that there is a strong empirical relationship between exports and imports, no matter how measured.

\section{Empirical Results}

\subsection{Unit Root Tests}

The unit root tests are first performed to examine the time-seriesproperties of the model series. Such an analysis assumes particular importance for the variables measured in terms of the ratios of possibly two I(d) series such as the ratio of imports to GDP and ratio of exports to GDP, where the order of integration d $\geqslant 1$ (see Levy 2000). ت It may seem puzzling to recognise the I(d) property of the ratio of possibly $\mathrm{I}(\mathrm{d})$ series of imports (and exports) and GDP. The unit root tests of Maddala and Wu (1999), Hadri (2000), and Breitung (2002), Levin, Lin and Chu (LLC) (2002) and Im, Pesaran and Shin (IPS) (2003) are performed to examine the I(d) properties of the model series. The unit root tests are performed using the model estimated with (i) individual intercept (Model I) and (ii) individual intercept and trend (Model II).

Maddala and $\mathrm{Wu}(1999)$ use Fisher-type tests and combine p-values from the individual unit root tests, such as the augmented Dickey-Fuller (ADF) (Dickey and Fuller 1981) and Phillips-Perron (PP) (Phillips and Perron 1988 ) tests, and construct the test statistic for the null hypothesis. Hadri (2000) extends the KPSS (Kwiatkowski, Phillips, Schmidt, and Shin) test (Kwiatkowski et al. 1992) to panel setting and develops the test statistic for the null hypothesis of no unit root against the alternative hypothesis of a unit root in the given series. The unit root tests of Hadri (2000), Breitung (2002) and Levin, Lin, and Chu (20)2) assume a common unit root process across cross-sectional units. Im, Pesaran, and Shin (2003) estimate the ADF model separately for each cross-sectional unit and take an average of the individual ADF t-statistics across cross-sectional units to construct the test statistic. The IPS test allows heterogeneity in the intercept as well as slope parameters of the model. All the tests test the null hypothesis of a unit root, except for the unit root test of Hadri (2000). The alternative hypothesis is (i) no unit root in LLC and Breitung tests and (ii) no unit root in some cross-sections in ADF-Fisher, PP-Fisher and IPS tests. The results obtained from the unit root tests suggest that most tests do not reject the null hypothesis of a unit root in the level series, but reject the null in the first-differenced series (Table 1). The unit root analysis provides dominant support for the I(1) properties of the model series.

Table 1: Panel unit root tests.

$\begin{array}{lll}\text { Test Statistics } & \text { Mevel Series } & \text { M }\end{array}$




$\begin{array}{lllll}\text { ADF Fisher } \chi^{2} & 21.65(1.00) & 51.37(0.34) & 423.71^{*}(0.00) & 336.87^{*}(0.00) \\ \text { Statistic } & & & & \\ \text { PP Fisher } \chi^{2} \text { Statistic } & 24.84(1.00) & 38.32(0.84) & 516.47^{*}(0.00) & 420.79^{*}(0.00) \\ \text { Hadri Z-Statistic } & 14.84^{*}(0.00) & 15.67^{*}(0.00) & 0.41(0.34) & 2.19^{*}(0.01) \\ \text { LLC t-Statistic } & 1.91(0.97) & 1.39(0.92) & -17.74^{*}(0.00) & -16.59^{*}(0.00) \\ \text { IPS W-Statistic } & 3.49(1.00) & 2.03(0.98) & -19.85^{*}(0.00) & -16.05^{*}(0.00) \\ & \text { Model II: Individual Intercept and Trend } & & 321.53^{*}(0.00) & 258.36^{*}(0.00) \\ \text { ADF Fisher } \chi^{2} & 61.64^{* * *}(0.09) & 82.79^{*}(0.001) & & 389.05^{*}(0.00) \\ \text { Statistic } & & & 672.67^{*}(0.00) & 3.46^{*}(0.00) \\ \text { PP Fisher } \chi^{2} \text { Statistic } & 46.78(0.52) & 42.63(0.69) & -11.20^{*}(0.00) & -10.62^{*}(0.00) \\ \text { Hadri Z-Statistic } & 6.81^{*}(0.00) & 8.77^{*}(0.00) & -13.43^{*}(0.00) & -14.31^{*}(0.00) \\ \text { Breitung t-Statistic } & 0.22(0.59) & 1.12(0.87) & -16.64^{*}(0.00) & -13.26^{*}(0.00) \\ \text { LLC t-Statistic } & 0.78(0.78) & 0.18(0.57) & -2.16^{* *}(0.02) & \end{array}$

Notes: (1) Figures in parentheses are p-values; $(2)^{*},{ }^{* *}$ and ${ }^{* * *}$ indicate statistical significance and implied rejection of the null at $1 \%, 5 \%$ and $10 \%$ levels, respectively. Some of the statistics are on the border line of critical region and, thus, strictly do not reject the null at indicated level of significance.

\subsection{Long-Run Estimates and Tests for Panel Cointegration}

\subsubsection{Standard Panel Data Estimates}

The long-run model is estimated first using the standard panel data estimators. The estimates of the common pooled model, $\mathrm{X}_{\mathrm{it}}=\alpha+\beta \mathrm{MM}_{\mathrm{it}}+\varepsilon_{\mathrm{it}}$, suggest that the numerical magnitude of the slope parameter of imports, $\beta$, is close to unity (Table 2). The common pooled model (CPM), however, assumes identical intercept, $\alpha$, and slope, $\beta$, parameters across all time-periods and all cross-sectional units. The CPM estimates could be biased due to the neglected heterogeneity across individual cross-sectional members. The CPM can be transformed into the fixed effects model, $\mathrm{X}_{\mathrm{it}}=\alpha_{\mathrm{i}}+\beta \mathrm{MM}_{\mathrm{it}}+\varepsilon_{\mathrm{it}}$, to account for the heterogeneity in intercept across cross-sectional units. The fixed effects model (FEM) becomes random effects model (REM) when $\alpha_{i}=\alpha+v_{i}$ so that $X_{i t}=$ $\alpha+\beta \mathrm{MM}_{\mathrm{it}}+\left\{\varepsilon_{\mathrm{it}}+v_{\mathrm{i}}\right\}$; where $v_{i}$ is a zero-mean standard random variable. The REM represents the GLS transform of FEM and it assumes that the unobserved individual effects are distributed randomly and are uncorrelated with regressors. The estimated coefficient of imports, $\beta$, is close to unity, and it carries the correct positive sign consistent with the economic theory. The t-ratios reject $\mathrm{H}_{0}: \beta=0$ as well as $\mathrm{H}_{0}: \beta=1$ across both FEM and REM estimates. These results point towards the sustainability of CADs and validity of long-run IBC.

Table 2: Standard panel data estimates of the long-run model.

\begin{tabular}{|c|c|c|c|c|}
\hline \multirow[b]{2}{*}{ Estimator } & \multirow[b]{2}{*}{$\alpha$} & \multirow[b]{2}{*}{$\beta$} & \multicolumn{2}{|c|}{ t-Ratios } \\
\hline & & & $\mathrm{H}_{0}: \beta=0$ & $\mathrm{H}_{0}: \beta=1$ \\
\hline CPM & $-4.5823^{*}(-13.56)$ & 1.1572 & $131.78^{*}$ & $17.90^{*}$ \\
\hline \multicolumn{5}{|l|}{ FEM } \\
\hline Individual & & 1.1253 & $58.81^{*}$ & $6.55^{*}$ \\
\hline Time & & 1.1529 & $129.97^{*}$ & $17.23^{*}$ \\
\hline Individual \& Time & & 1.0271 & $41.72^{*}$ & 1.10 \\
\hline \multicolumn{5}{|l|}{ REM } \\
\hline Individual & $-3.7348^{*}(-3.98)$ & 1.1318 & $65.36^{*}$ & $7.61^{*}$ \\
\hline Time & $-4.5175^{*}(-12.25)$ & 1.1552 & $132.25^{*}$ & $17.77^{*}$ \\
\hline Individual \& Time & $-1.8558(-1.62)$ & 1.0754 & $52.09^{*}$ & $3.65^{*}$ \\
\hline RCM & $0.6560(0.20)$ & 0.9385 & $9.79^{*}$ & -0.64 \\
\hline MG & $0.5296(0.83)$ & 0.9388 & $51.46^{*}$ & $-3.35^{*}$ \\
\hline AB-GMM & $0.1067^{*}(9.72)$ & 0.8956 & $217.16^{*}$ & $-25.31^{*}$ \\
\hline
\end{tabular}

Notes: (1) Figures in parentheses are the t-ratios; (2) * indicates the statistical significance and implied rejection of the null hypothesis at $1 \%$ level of significance; $(3) \chi^{2}=0.64$ ( $p$-value $=0.43$ ) for the Hausman test (Hausman 1978) for the choice between FEM and REM; (4) $J=$ 24.00 ( $\mathrm{p}$-value $=0.90$ ) for the null hypothesis of orthogonality (no correlation) between regressors and residual term in the AB-GMM estimator:

The FEM estimators are statistically consistent but may not be most efficient, while the REM estimators are more efficient. The Hausman test (Hausman 1978) is performed to test the null hypothesis that coefficients obtained from the efficient REM are the same as those obtained from the consistent FEM. The Hausman test does not reject the null hypothesis of no difference between fixed effects and random effects estimators and, 
thus, supports the use of REM. Nevertheless, the REM treats intercept terms, $\alpha_{i}$, as random, but $\beta_{i}=\beta$ for all i. In contrast, the random coefficient model (RCM) of Swamy (1970) treats slope parameters, $\beta_{\mathrm{i}}$, also as random. The $\beta_{\mathrm{i}}$ are allowed to vary over time in response to the unspecified structural factors. The RCM uses the generalized least squares (GLS) and computes the GLS matrix weighted estimator, as compared to the mean group (MG) estimator of Pesaran, Shin, and Smith (1999), which computes simple weighted average of the parameter vectors. The RCM estimates suggest that the slope coefficient of imports, $\beta$, is significantly different from zero, but insignificantly different from one. One unit of imports is equivalent to one unit of exports, resulting in a long-run balance between the inflow and outflow of resources.

The pooled, FEM, REM and RCM estimates become biased and inconsistent in the presence of possible nonorthogonality of regressors to the residual process. The commonly used method to alleviate endogeneity is the generalized method of moments (GMM) estimator of Hansen (1982). While the GMM estimator has desirable properties in large samples, the lagged regressors used to resolve endogeneity could be weak instruments for the endogenous regressors. Also, using standard instrument setup may severely restrict the number of data points or the instruments that could be used in such conventional GMM estimator. Arellano and Bond (1991) develop an efficient rendition of the GMM to take a robust account of the endogeneity of regressors. The study, therefore, uses the GMM estimator of Arellano and Bond (AB-GMM) (Arellano and Bond 1991) to account for the non-orthogonality of imports to the residual process. The results obtained from AB-GMM support the sustainability of CADs and validity of IBC (Table 2). The long-run slope parameter of imports is close to unity, and the tratios reject both $\mathrm{H}_{0}: \beta=0$ and $\mathrm{H}_{0}: \beta=1$ in the AB-GMM estimates.

The panel data models are premised on the basic assumption (known as pooling assumption) that at least some of the parameters are same across the panel. This assumption becomes invalid and the results obtained from both static and dynamic panels become biased, if the model contains a heterogeneous set of parameters in that some of the parameters actually vary across the panel. Pesaran, Shin, and Smith (1999) suggest using the mean group (MG) estimator to resolve the bias arising from the heterogeneous slopes in the dynamic panels. The MG estimator derives the long-run parameters for the panel from an average of the long-run parameters obtained from the autoregressive distributed lag (ARDL) models for the individual countries. The MG estimates cross-validate the evidence and support the sustainability of CADs and validity of IBC. The t-ratios reject both $\mathrm{H}_{0}: \beta=0$ and $\mathrm{H}_{0}: \beta=1$ in MG estimates (Table 2).

\subsubsection{Panel FMOLS and DOLS Estimates}

The regression estimates would be 'spurious' and the statistical inference be void and invalid, if the model series are not cointegrated. Pedroni $(2000,2001)$ extends the time-series fully-modified OLS (FMOLS) estimator of Phillips and Hansen (1990) and dynamic OLS (DOLS) estimator of Saikkonen (1991) and Stock and Watstandard OLS regression and then makes a non-parametric correction to account for the endogeneity-bias and serial-correlation that may show up in the standard OLS residuals. The estimates of the long-run parameters and associated t-statistics are adjusted to correct for the bias arising from the endogeneity of regressors and serial-correlation of residuals. The DOLS estimator augments the static regression model with extra lags and leads terms in first-differences to correct for the serial-correlation and endogeneity bias that may be embodied in the standard OLS estimates. The study uses the FMOLS and DOLS estimators of Pedroni (2000 and 2001) to re-estimate the model and cross-examine the evidence. The DOLS estimation is carried out using the alternative lags and leads structures of two, $k=\{-2,0,+2\}$, and four, $k=\{-4,0,+4\}$, for the first-differenced dynamic regressors; where $\mathrm{k}$ denotes the lag structure of the model. The results obtained from the panel FMOLS and DOLS estimators suggest that the slope parameter of imports is close to unity in both the models estimated 'with' and 'without' time dummies (Table 3). The tratios reject $\mathrm{H}_{0}: \beta=0$, but not $\mathrm{H}_{0}: \beta=1$, in the model estimated 'without' time dummies. These results support the sustainability of CADs and validity of IBC.

Table 3: Panel FMOLS and DOLS estimates of the long-run model.

$\begin{array}{lllr}\text { Model } & \beta & \mathrm{H}_{0}: \beta=\mathbf{0} & \mathrm{H}_{0}: \beta \\ \begin{array}{l}\text { (A) With Time } \\ \text { Dummies } \\ \text { (B) Without }\end{array} & 1.07 & 0.14 & 0.01 \\ \text { Time } & 0.98 & 0.03 & 0.00 \\ \text { Dimatios } & & & \end{array}$

Dunnnies 


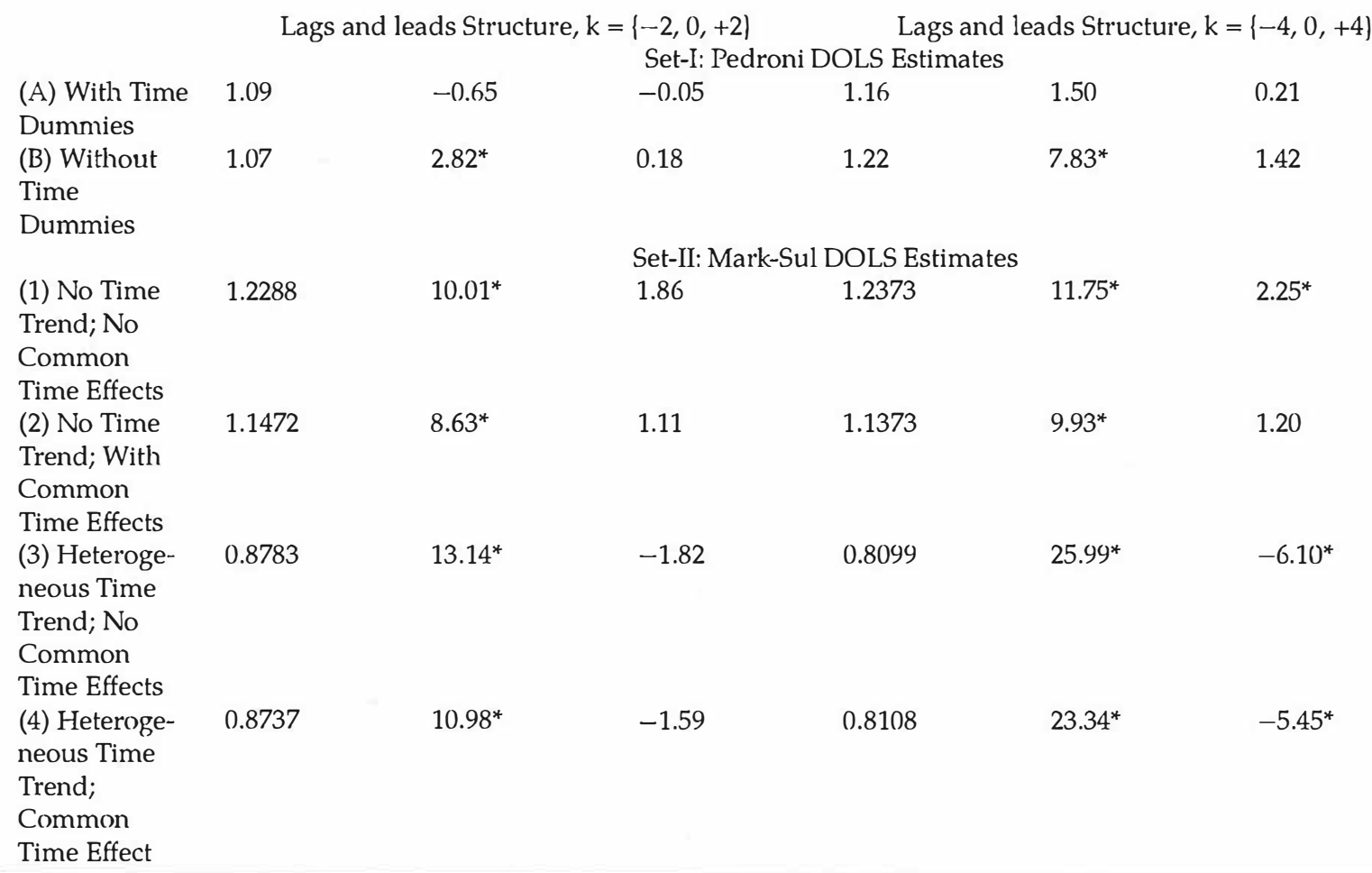

Notes: (1) $k$ denotes the lags and leads structure in the DOLS estimator; $(2)^{*}$ indicates the statistical significance and implied rejection of the null hypothesis at 1\% level; (3) The number of lags for the kernel estimator for the variance is set at four in both the models estimated with the lags and leads structures of $k=\{-2,0,+2\}$ and $k=\{-4,0,+4\}$ in the DOLS estimator; (4) The FMOLS estimation is carried out using the lag-length of four for the Bartlett kernel.

An increase in economic and financial integration among the OECD countries could relax the external budget constraints in that it is easier for the member countries to borrow and run larger CADs. It is, therefore, necessary to account for the cross-sectional dependence among the panel members. The DOLS estimator of Mark and Sul (2003) considers the cointegrating vector as homogeneous across individuals, but allows for individual heterogeneity through disparate short-run dynamics, individual-specific fixed effects, and individual-specific time trends. The Mark-Sul DOLS permits a limited degree of cross-sectional dependence through the presence of time-specific effects. The Mark-Sul DOLS estimates reinforce the close-to-unity slope parameter of imports.

\pm The t-ratios reject $\mathrm{H}_{0}: \beta=0$, but not $\mathrm{H}_{0}: \beta=1$, in all the models estimated with the lags and leads structure $\cong$ of $\mathrm{k}=\{-2,0,+2\}$ and with (i) no time trend and no common time effects (Model 1), (ii) no time trend and with common time effects (Model 2), (iii) heterogeneous time trend and no common time effects (Model 3), and (iv) heterogeneous time trend and common time effects (Model 4) (Table 3). The sensitivity analysis is carried out to account for the possible selection bias that could arise from the use of a given lags and leads structure in DOLS. The results are generally robust to the use of both higher and lower lags and leads structures of firstdifferenced dynamic regressors, suggesting the non-fragility of linkage between trade inflows and outflows (Table 3, Annexure 1).

\subsubsection{Residual-Based Tests for Cointegration}

The residual-based cointegration estimators of Kao (1999) and Pedroni (1999, 2004, and 2007) are used to test the null hypothesis of no cointegration against the alternative hypothesis of cointegration, and examine the equilibrium relationship between imports and exports. These estimators with a single cointegrating vector are the panel extensions of the time-series two-step estimator of Engle and Granger (1987). The residual-based twostep panel cointegration estimators analogously involve the sequential estimation of the pooled static regression model in levels,

$$
\mathrm{y}_{\mathrm{it}}=\alpha_{\mathrm{i}}+\delta_{\mathrm{i}} \mathrm{t}+\sum_{\mathrm{m}=1}^{\mathrm{M}} \beta_{\mathrm{mi}} \mathrm{x}_{\mathrm{mit}}+\mathrm{e}_{\mathrm{it}}
$$

and then the estimation of the auxiliary, $\delta \mathrm{e}_{\mathrm{it}}=\rho \mathrm{e}_{\mathrm{it}-1}+\mu_{\mathrm{it}}$, or augmented auxiliary, $\delta \mathrm{e}_{\mathrm{it}}=\rho \mathrm{e}_{\mathrm{it} \mathrm{-1}}+\sum_{\mathrm{j}=1}^{\mathrm{k}} \xi_{\mathrm{j}} \delta \mathrm{e}_{\mathrm{it}-1}+$ $\mu_{\mathrm{it}}$, regression model to test $\mathrm{H}_{0}$ : e(t)I(1) (no cointegration among $\mathrm{I}(1)$ variables) against $\mathrm{H}_{1}$ : $\mathrm{e}(\mathrm{t}) \mathrm{I}(0)$ (cointegration among $\mathrm{I}(1)$ variables). The index $\mathrm{i} \in[1,2, \ldots, \mathrm{N}]$ in model eq. (16) indicates the individual cross-sectional 
units, index $\mathrm{t} \in[1,2, \ldots, \mathrm{T}]$ denotes the time period, and $\mathrm{m} \in[1,2, \ldots, \mathrm{M}]$ represents the number of regressors. The $\beta_{\mathrm{mi}} \in[1 \mathrm{i}, 2 \mathrm{i} \ldots, \mathrm{Mi}]$ denote the slope parameters, and $\alpha_{\mathrm{i}} \in[1,2 \ldots, \mathrm{N}]$ represent the number of member-specific intercept (fixed effects) parameters. Model eq. (16) represents the fixed effects model, with $\alpha_{\mathrm{i}}$ being the member-specific intercept term. Pedroni allows both cointegrating vectors and model residuals to vary across cross-sectional units. The intercept, $\alpha_{i}$, and slope, $\beta_{\mathrm{mi}}$, parameters, as such, can vary across crosssectional units. ${ }^{2}$ The model series are cointegrated if the residuals are stationary, and non-cointegrated if the residuals are non-stationary.

Pedroni provides seven test statistics to test the 'within' and 'between' effects in the panel. Of these, four statistics are based on pooling 'within' dimensions (panel cointegration statistics). These statistics involve pooling the AR parameters across different cross-sections of the panel for unit root test on the model residuals. The panel test statistics amount to computing the average test statistics for the cointegrating regressions, in a timeseries setting, across different cross-sections of the panel. The remaining three test statistics are based on pooling 'between' dimensions (group-mean panel cointegration statistics). These test statistics involve avcraging the AR parameters across each cross-section in the panel for unit root test on the model residuals.

i. Panel v-statistic:

$$
\mathrm{T}^{2} \mathrm{~N}^{3 / 2} \mathrm{Z}_{\hat{\nu} N T} \equiv \mathrm{T}^{2} \mathrm{~N} 3 / 2\left(\sum_{\mathrm{i}=1}^{\mathrm{N}} \sum_{\mathrm{t}=1}^{\mathrm{T}} \hat{L}_{11 \mathrm{i}}^{-2} \hat{e}_{\mathrm{it}-1}^{2}\right)^{-1}
$$

ii. Panel p-statistic:

$$
\mathrm{T} \sqrt{\mathrm{N}} Z_{\hat{\rho} \mathrm{NT}^{-1}} \equiv \mathrm{T} \sqrt{\mathrm{N}}\left(\sum_{i=1}^{N} \sum_{t=1}^{T} \hat{L}_{1 l i}^{-2} \hat{e}_{i t-1}^{2}\right)^{-1} \sum_{i=1}^{N} \sum_{t=1}^{T} \hat{L}_{11 i}^{-2}\left(\hat{e}_{\mathrm{it}-1} \Delta \bar{e}_{\mathrm{it}}-\hat{\lambda}_{\mathrm{i}}\right)
$$

iii. Panel t-statistic (non-parametric):

$$
\mathrm{Z}_{\mathrm{tNT}} \equiv\left(\tilde{\sigma}_{\mathrm{NT}}^{2} \sum_{\mathrm{i}=1}^{\mathrm{N}} \sum_{\mathrm{t}=1}^{\mathrm{T}} \hat{L}_{11 \mathrm{i}}^{-2} \hat{e}_{\mathrm{it}-1}^{2}\right)^{-1 / 2} \sum_{\mathrm{i}=1}^{\mathrm{N}} \sum_{\mathrm{t}=1}^{\mathrm{T}} \hat{L}_{11 \mathrm{i}}^{-2}\left(\hat{e}_{\mathrm{it}-1} \delta \widehat{e}_{\mathrm{it}}-\hat{\lambda}_{\mathrm{i}}\right)
$$

iv. Panel t-statistic (parametric):

$$
Z_{\mathrm{tNT}}^{*} \equiv\left(\hat{S}_{\mathrm{NT}}^{* 2} \sum_{\mathrm{i}=1}^{\mathrm{N}} \sum_{\mathrm{t}=1}^{\mathrm{T}} \hat{L}_{11 \mathrm{i}}^{-2} \hat{e}_{\mathrm{it}-1}^{* 2}\right)^{-1 / 2} \sum_{\mathrm{i}=1}^{\mathrm{N}} \sum_{\mathrm{t}=1}^{\mathrm{T}} \hat{L}_{11 \mathrm{i}}^{-2}\left(\hat{e}_{\mathrm{it}-1}^{*} \Delta \hat{e}_{\mathrm{it}}^{*}\right)
$$

v. Group p-statistic:

$$
T N^{-1 / 2} \tilde{Z}_{\hat{p} N T^{-1}} \equiv T N^{-1 / 2} \sum_{i=1}^{N}\left(\sum_{t=1}^{T} \hat{e}_{i t-1}^{2}\right)^{-1} \sum_{t=1}^{T}\left(\hat{e}_{i t-1} \Delta \hat{e}_{i t}-\hat{\lambda}_{i}\right)
$$

vi. Group t-statistic (non-parametric):

$$
\mathrm{N}^{-1 / 2} \tilde{Z}_{\mathrm{tNT}} \equiv \mathrm{N}^{-1 / 2} \sum_{\mathrm{i}=1}^{\mathrm{N}}\left(\hat{\sigma}_{i}^{2} \sum_{\mathrm{t}=1}^{\mathrm{T}} \hat{e}_{\mathrm{it}-1}^{2}\right)^{-1 / 2} \sum_{\mathrm{t}=1}^{\mathrm{T}}\left(\hat{e}_{\mathrm{it}-1} \delta \hat{e}_{\mathrm{it}}-\hat{\lambda}_{\mathrm{i}}\right)
$$

vii. Group t-statistic (parametric):

$$
\mathrm{N}^{-1 / 2} \tilde{Z}_{\mathrm{iNT}}^{*} \equiv \mathrm{N}^{-1 / 2} \sum_{\mathrm{i}=1}^{\mathrm{N}}\left(\sum_{\mathrm{t}=1}^{\mathrm{T}} \hat{s}_{\mathrm{i}}^{*} \hat{e}_{\mathrm{it}-1}^{* 2}\right)^{-1 / 2} \sum_{\mathrm{t}=1}^{\mathrm{T}} \hat{e}_{\mathrm{it}-1}^{*} \Delta \hat{e}_{\mathrm{it}}^{*}
$$

In test statistics eqs (17) to (23), $\hat{\lambda}_{\mathrm{i}}=\frac{1}{\mathrm{~T}} \sum_{\mathrm{s}=1}^{\mathrm{k}_{\mathrm{i}}}\left(1-\frac{\mathrm{s}}{\mathrm{k}_{\mathrm{i}}+1}\right) \sum_{\mathrm{t}=\mathrm{s}+1}^{\mathrm{T}} \hat{\mu}_{\mathrm{it}} \hat{\mu}_{\mathrm{it}-\mathrm{s}}, \hat{s}_{\mathrm{i}}^{2} \equiv \frac{1}{\mathrm{~T}} \sum_{\mathrm{t}=1}^{\mathrm{T}} \hat{\mu}_{\mathrm{it}}^{2} \hat{\sigma}_{\mathrm{i}}^{2}=\hat{s}_{\mathrm{i}}^{2}+2 \hat{\lambda}_{\mathrm{i}}, \hat{v}_{\mathrm{NT}}^{2} \equiv$ $\frac{1}{N} \sum_{i=1}^{\mathrm{N}} \hat{L}_{11 \mathrm{i}}^{-2} \hat{\sigma}_{\mathrm{i}}^{2}, \hat{s}_{\mathrm{i}}^{* 2} \equiv \frac{1}{\mathrm{i}} \sum_{\mathrm{t}=1}^{\mathrm{T}} \hat{\mu}_{\mathrm{it}}^{* 2}, \hat{s}_{\mathrm{NI}}^{* 2} \equiv \frac{1}{\mathrm{~N}} \sum_{\mathrm{i}=1}^{\mathrm{N}} \hat{s}_{\mathrm{i}}^{* 2}$ and $\hat{L}_{11 \mathrm{i}}^{2}=\frac{1}{\mathrm{~T}} \sum_{\mathrm{t}=1}^{\mathrm{T}} \hat{\eta}_{\mathrm{it}}^{2}+\frac{2}{\mathrm{~T}} \sum_{\mathrm{s}=1}^{\mathrm{k}_{\mathrm{i}}}\left(1-\frac{\mathrm{s}}{\mathrm{k}_{\mathrm{t}}+1}\right) \sum_{\mathrm{t}=\mathrm{s}+1}^{\mathrm{T}} \hat{\eta}_{\mathrm{it}} \hat{\eta}_{\mathrm{it}-\mathrm{s}}$. The residuals $\hat{\mu}_{\mathrm{it}}, \hat{\mu}_{\mathrm{it}}^{*}$ and $\hat{\eta}_{\mathrm{it}}$ are obtained from the auxiliary regression models: $\hat{e}_{\mathrm{it}}=\hat{\gamma}_{\mathrm{i}} \hat{e}_{\mathrm{it}-1}+\hat{\mu}_{\mathrm{it}}, \hat{e}_{\mathrm{it}}=\hat{\gamma}_{\mathrm{i}} \hat{e}_{\mathrm{it}-1}+$ $\sum_{\mathrm{k}=1}^{\mathrm{K}_{\mathrm{i}}} \hat{\gamma}_{\mathrm{ik}} \Delta \hat{e}_{\mathrm{it}-\mathrm{k}}+\hat{\mu}_{\mathrm{it}}^{*}$ and $\Delta \mathrm{y}_{\mathrm{it}}=\sum_{\mathrm{m}=1}^{\mathrm{M}} \hat{b}_{\mathrm{mi}} \Delta \mathrm{x}_{\mathrm{mi}, \mathrm{t}}+\hat{\eta}_{\mathrm{it}}$. The test statistics are distributed as standard normal under the appropriate standardization based on the moments of the vector of Brownian motion functionals. All the statistics are one-sided tests and have a critical value of -1.64 , except for $v$-statistic which has a critical value of 1.64. The null hypothesis of no cointegration between imports and exports implies that the international intertemporal budget constraint (solvency constraint) is not satisfied and the CADs are not sustainable.

The results suggest that all the test statistics (weighted) are well within the rejection zone in the model estimated with trend, except for the group p-statistic which falls inside the acceptance region (Table 4). In the model estimated without trend, all the test statistics consistently reject the null hypothesis of no cointegration and suggest the equilibrium relationship between the model series. In the model estimated with time dummy, all the test statistics are in the rejection region, except for the panel and group ADF-statistics which fall inside the acceptance region. All the unweighted panel statistics consistently reject the null hypothesis of no cointegration and reinforce the cointegrating relationship between the model series. The Pedroni tests, thus, provide dominant support for the presence of long-run equilibrium relationship between imports and exports.

Table 4: Residual-based tests for panel cointegration between imports and exports. 


\begin{tabular}{|c|c|c|c|c|c|}
\hline \multicolumn{6}{|c|}{$\begin{array}{l}\mathrm{H}_{0}: \text { No Cointegration; } \mathrm{H}_{1}: \text { Cointegration } \\
\quad \text { Pedroni (1999, } 2004 \text { and 2007) Tests; Lag } \mathrm{k}=8\end{array}$} \\
\hline $\begin{array}{l}\text { Test } \\
\text { Statistics }\end{array}$ & Trend & $\begin{array}{l}\text { Weighted } \\
\text { No Trend }\end{array}$ & Time Dummy & Unweighted & $\begin{array}{l}\text { Critical } \\
\text { Values }\end{array}$ \\
\hline \multicolumn{6}{|c|}{ Within Dimensions Panel Statistics } \\
\hline Panel v-statistic & $2.42^{*}$ & $3.18^{*}$ & $2.92^{*}$ & $2.52^{*}$ & 1.64 \\
\hline Panel $\rho$-statistic & $-2.43^{*}$ & $-4.66^{*}$ & $-3.11^{*}$ & $-4.71^{*}$ & -1.64 \\
\hline Panel PP-statistic & $-3.32^{*}$ & $-4.45^{*}$ & $-2.64^{*}$ & $-4.54^{*}$ & -1.64 \\
\hline Panel & $-4.59^{*}$ & $-3.32^{*}$ & -0.68 & $-4.18^{*}$ & -1.64 \\
\hline ADF-statistic & & & & & \\
\hline \multicolumn{6}{|c|}{ Between Dimensions Group Statistics } \\
\hline Group p-statistic & -0.36 & $-3.22^{*}$ & $-2.13^{*}$ & $-3.22^{*}$ & -1.64 \\
\hline Group & $-2.16^{*}$ & $-4.44^{*}$ & $-2.45^{*}$ & $-4.44^{*}$ & -1.64 \\
\hline PP-statistic & & & & & \\
\hline Group & $-4.99^{*}$ & $-3.45^{*}$ & -0.71 & $-3.45^{*}$ & -1.64 \\
\hline \multicolumn{6}{|c|}{ Kao (1999) Test } \\
\hline Lags & $k=1$ & $k=2$ & $k=3$ & $\mathrm{k}=4$ & \\
\hline ADF Statistic & $-4.59^{*}$ & $-2.50^{*}$ & $-2.42^{*}$ & $-2.69^{*}$ & \\
\hline & $(0.0000)$ & $(0.0062)$ & $(0.0078)$ & $(0.0036)$ & \\
\hline
\end{tabular}

Notes: (1) The model is estimated for $\mathrm{N}=24$ and $\mathrm{T}=37$; (2) All reported values in the Pedroni tests are distributed $\mathrm{N}(0,1)$ under the null of a unit root or no cointegration. "Weighted" denotes that panel statistics are weighted by long-run variances. "Unweighted" denotes that panel statistics are unweighted by long-run variances; (3) Kao (1999) tests are performed using the Newey-West automatic bandwidth selection and Bartlett kernel. Figures in parentheses in Kao (1999) tests are p-values; (4)* indicates statistical significance and implied rejection of the null.

The sensitivity analysis suggests that the results are robust to the use of alternative lag structure of $k=4$. All the test statistics consistently reject the null hypothesis of no cointegration, except for the group p-statistic which does not reject the null in the model estimated with trend (Annexure 2). The Kao test cross-validates the evidence and provides an unambiguous support for the equilibrium relationship between international trade inflows and outflows. The Kao test statistics strongly reject the null hypothesis of no cointegration (at $1 \%$ level) in all the models estimated with the alternative lag structures of $k=1,2,3,4$ and, thus, point towards long-run synchronization between imports and exports (Table 4).

\subsubsection{System-Based Rank Tests for Cointegration}

The residual-based cointegration estimators of Kao (1999) and Pedroni (2004 and 2007) impose the restrictive assumption of a unique cointegrating vector. The arbitrariness involved in normalization of dependent variable and the imposition of, at the most, a single cointegrating vector on the model series could impinge upon the efficiency of residual-based single-equation estimators. The panel unit root tests of Maddala and Wu (1999), as extended to the vector autoregression (VAR)-based system methodology of Johansen (1991), are performed to test the null hypothesis of no panel cointegration in a system setting. The estimation is carried out using the alternative lag structures of $k=4$ and $k=8$ for the VAR model so as to assess the robustness of results across model structures. The results obtained from VAR-based Maddala-Wu-Johansen rank tests (Maddala and Wu 1999; Johansen, 1991) suggest that both $\lambda$-trace and $\lambda$-max tests consistently reject the null of no panel cointegration and reinforce the equilibrium relationship between imports and exports (Table 5). The results remain robust to variations in model structure in that the cointegrating relationship remains unaltered in all the models estimated using the alternative lag structures of $k=1,2,3,5,6,7$ (Annexure 3). The support for cointegration between imports and exports is consistent with the evidence obtained from the single-equation cointegration estimators of Kao (1999) and Pedroni (2004 and 2007).

Table 5: Maddala-Wu-Johansen rank tests for the long-run model.

\begin{tabular}{lllllllll}
\hline & \multicolumn{7}{c}{$\mathrm{H}_{0}$ : No Cointegration; $\mathrm{H}_{1}$ : Cointegration } \\
VAR & & \multicolumn{7}{c}{$\lambda$-trace Rank Test } \\
Lag, $\mathrm{k}$ & $\mathrm{H}_{0}$ & $\mathrm{H}_{1}$ & $\lambda$-trace & $\mathrm{p}$-value & $\mathrm{H}_{0}$ & $\mathrm{H}_{1}$ & $\lambda$-max & $\mathrm{p}$-value \\
\hline 4 & $\mathrm{r}=0$ & $\mathrm{r} \geq 1$ & $101.60^{*}$ & 0.0000 & $\mathrm{r}=0$ & $\mathrm{r}=1$ & $95.72^{*}$ & 0.0001 \\
& $\mathrm{r} \leq 1$ & $\mathrm{r}=2$ & $62.48^{* *}$ & 0.0782 & $\mathrm{r} \leq 1$ & $\mathrm{r}=2$ & $62.48^{* * *}$ & 0.0782 \\
8 & $\mathrm{r}=0$ & $\mathrm{r} \geq 1$ & $252.50^{*}$ & 0.0000 & $\mathrm{r}=0$ & $\mathrm{r}=1$ & $226.80^{*}$ & 0.0000
\end{tabular}




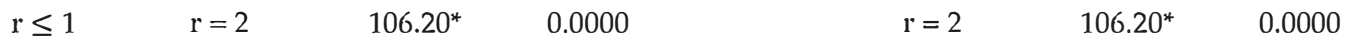

Notes: (1) Model is estimated using an intercept (but no trend) term; (2) The p-values are based on MacKinnon, Haug, and Michelis (1999); (3) * and *** indicate the statistical significance and implied rejection of the null hypothesis at $1 \%$ and $10 \%$ levels, respectively; (4) $r$ denotes the number of cointegrating vectors.

The above analysis provides dominant support for the sustainability of CADs and validity of IBC. The imports and exports may drift apart in the short-run, but have a tendency to converge towards equilibrium in the long-run. Both conventional and recent panel data estimators provide consistent support for the presence of long-run equilibrium relationship between imports and exports. The results are consistent with several studies supporting the sustainability of CADs and validity of IBC (Trehan and Walsh 1991; Husted 1992; Liu and Tanner 1996; Bergin and Sheffrin 2000; Wu 2000; Wu, Chen, and Lee 2001; Arize 2002; Irandoust and Ericsson 2004; Matsubayashi 2005; Chu et al. 2007), but are inconsistent with some studies suggesting the unsustainability of CADs and violation of IBC (Otto 1992; Wickens and Uctum 1993; Liu and Tanner 1996; Wu, Fountas, and Chen 1996). The support for long-run relationship between trade flows is consistent with the intertemporal view, which suggests that the CADs are only short-run phenomena and are balanced by future surpluses. Numerous factors tend to drive imports and exports simultaneously including the efficient export promotion strategies, incentives for exports, flexible exchange rate system, and the systematic government interventions in terms of the use of macroeconomic stabilisation strategies. The loss of net national wealth arising from large CADs acts as an automatic corrective device in that it calls for the need for government intervention and the adoption of appropriate policy measures to ensure the sustainability of CADs. The long-run IBC itself seems to have been the major driving force behind the long-run equilibrium relationship between imports and exports and the close-to-unity parameter of imports.

The current account can alternatively be expressed in terms of the quotient (q) of saving to investment, $\mathrm{q}=\mathrm{S} / \mathrm{I}$, or the difference between saving and investment, $(\mathrm{S}-\mathrm{I})=(\mathrm{X}-\mathrm{M})$; where $\mathrm{S}$ denotes saving. The current account is in (i) deficit when $\mathrm{q}=\mathrm{S} / \mathrm{I}<1$ or $(\mathrm{S}-\mathrm{I})<0$, (ii) surplus when $\mathrm{q}=\mathrm{S} / \mathrm{I}>1$ or $(\mathrm{S}-\mathrm{I})>0$ and (iii) balance when $\mathrm{q}=\mathrm{S} / \mathrm{I}=1 \mathrm{or}(\mathrm{S}-\mathrm{I})=0$. It follows that the CADs could be caused by the domestic factors (such as high investment relative to domestic saving, and high import growth in line with the boom in domestic economic activity) as well as the external factors (such as slowdown in the major trading partners, and significant declines in both export growth and export prices). The sustainability of external position also reflects the sustainability of fiscal position, given that the external imbalances are closely associated with the fiscal imbalances. The saving and investment decisions are conditioned by several intertemporal factors such as the consumption-smoothing considerations of consumers and the expected returns on investment projects undertaken by investors. The CADs driven by the investment decisions of the forward-looking and intertemporally optimizing rational agents are not a cause of concern in that the external borrowings used to finance domestic investment potentially lead to the higher economic growth and elevated income capacity to service and repay the external debt. There is a natural tendency towards convergence to long-run equilibrium between trade flows in a well-functioning economy with efficient market mechanism in place and no policy distortions. level of output and employment. The CADs need to be (i) managed at reasonable levels, (ii) supported by adequate financing, and (iii) freed from structural problems such as excessive reliance on the concentrated export markets. The current account imbalances serve as the leading indicators of emerging financial crisis, given that these imbalances are closely associated with economic performance of the economy. The support for the sustainably of CADs and validity of IBC suggests that the economies of the sample countries have intertemporally been performing well.

\section{Conclusions}

This study has estimated the intertemporal model for the relationship between imports and exports and examined the sustainability of CADs and validity of intertemporal budget constraint for a comprehensive set of 24 OECD countries. The balanced panel data model is estimated using several single-equation and system estimators to obviate the possible bias that could arise from the use of a given estimator and to assess the robustness of results across methodologies and test statistics. The study finds that the numerical magnitude of the slope parameter of imports is close to unity consistently across estimators. The standard panel data estimators support the sustainability of CADs and solvency of external position for the sample countries. The optimal FMOLS and DOLS estimator's cross-validate the evidence and reinforce the sustainability of CADs and validity of IBC. The residual-based single-equation and the VAR-based system cointegration estimators provide consistent support for the presence of long-run equilibrium relationship between imports and exports. The sample countries are not in violation of their international budget (solvency) constraint and there is close synchronization between 
trade inflows and outflows. The dominant support for the sustainability of CADs is consistent with the intertemporal view, which suggests that the CADs are only short-run phenomena and are balanced by future surpluses. The imports and exports may drift apart in the short-run, but have a tendency to converge towards equilibrium in the long-run. The long-run IBC itself seems to have been the major driving force behind the long-run equilibrium relationship between imports and exports and the close-to-unity parameter of imports. The economies of sample countries have intertemporally been performing well, and the macroeconomic stabilisation strategies seem to have been effective in correcting the market failures and maintaining the steady-state equilibrium relationship between the inflow and outflow of resources.

Table 6: Sensitivity of the panel DOLS estimates of the long-run model.

\begin{tabular}{|c|c|c|c|c|c|c|}
\hline \multirow[b]{2}{*}{ Model } & \multirow[b]{2}{*}{$\beta$} & \multicolumn{3}{|c|}{ t-Ratios } & \multicolumn{2}{|c|}{ t-Ratios } \\
\hline & & $\mathrm{H}_{0}: \beta=0$ & $\mathrm{H}_{0}: \beta=1$ & $\beta$ & $\mathrm{H}_{0}: \beta=0$ & $\mathrm{H}_{0}: \beta=1$ \\
\hline & \multicolumn{4}{|c|}{ Lags and leads Structure, $\mathrm{k}=\{-1,0,+1\}$} & \multicolumn{2}{|c|}{ Lags and leads Structure, $k=\{-3,0,+3\}$} \\
\hline & \multicolumn{6}{|c|}{ Set-I: Pedroni DOLS Estimates } \\
\hline (A) With Time & 1.08 & -0.74 & -0.05 & 1.12 & -0.32 & -0.03 \\
\hline \multirow{4}{*}{\multicolumn{7}{|c|}{$\begin{array}{l}\text { Dummies } \\
\text { (B) Without } \\
\text { Time } \\
\text { Dummies }\end{array}$}} \\
\hline & & & & & & \\
\hline & & & & & & \\
\hline & & & & & & \\
\hline & \multicolumn{6}{|c|}{ Set-II: Mark-Sul DOLS Estimates } \\
\hline (1) No Time & 1.1844 & $8.54^{*}$ & 1.33 & 1.2591 & $10.26^{*}$ & $2.11^{*}$ \\
\hline \multirow{2}{*}{\multicolumn{7}{|c|}{$\begin{array}{l}\text { Trend; No } \\
\text { Common }\end{array}$}} \\
\hline & & & & & & \\
\hline \multicolumn{7}{|l|}{ Time Effects } \\
\hline (2) No Time & 1.0814 & $6.73^{*}$ & 0.51 & 1.1660 & $9.43^{*}$ & 1.34 \\
\hline \multicolumn{7}{|l|}{ Trend: With } \\
\hline Common & & & & & & \\
\hline \multicolumn{7}{|l|}{ Time Effects } \\
\hline (3) Heteroge- & 0.8676 & $7.01^{*}$ & -1.07 & 0.8381 & $19.56^{*}$ & $-3.78^{*}$ \\
\hline \multirow{2}{*}{\multicolumn{7}{|c|}{ Trend; No }} \\
\hline & & & & & & \\
\hline \multicolumn{6}{|l|}{ Common } & \\
\hline (4) Heteroge- & 0.8749 & $6.34^{*}$ & -0.91 & 0.8427 & $17.11^{*}$ & $-3.19^{*}$ \\
\hline neous Time & & & & & & \\
\hline \multicolumn{7}{|l|}{ Trend; } \\
\hline \multicolumn{7}{|l|}{ Common } \\
\hline Time Effect & & & & & & \\
\hline
\end{tabular}

Notes: (1) $k$ denotes the lags and leads structure in the DOLS estimator; $(2)$ * indicates the statistical significance and implied rejection of the null hypothesis at $1 \%$ level; (3) The number of lags for the kernel estimator for the variance is set at four in both the models estimated with the lags and leads structures of $k=\{-1,0,+1\}$ and $k=\{-3,0,+3)$ in the DOLS estimator.

Table 7: Residual-based tests for panel cointegration between imports and exports.

\begin{tabular}{|c|c|c|c|c|c|}
\hline \multirow[b]{2}{*}{$\begin{array}{l}\text { Test } \\
\text { Statistic }\end{array}$} & \multicolumn{4}{|c|}{$\begin{array}{l}\mathrm{H}_{0}: \text { No Cointegration; } \mathrm{H}_{1}: \text { Cointegration } \\
\text { Pedroni (2004 and 2007) Tests, Lag k = } \\
\text { Weighted }\end{array}$} & \multirow[b]{2}{*}{$\begin{array}{l}\text { Critical } \\
\text { Values }\end{array}$} \\
\hline & Trend & $\begin{array}{l}\text { Weighted } \\
\text { No Trend }\end{array}$ & Time Dummy & Unweighted & \\
\hline \multicolumn{6}{|c|}{ Within Dimensions Panel Statistics } \\
\hline Panel v-statistic & $2.41^{*}$ & $3.18^{*}$ & $2.92^{*}$ & $2.52^{*}$ & 1.64 \\
\hline Panel p-statistic & $-2.43^{*}$ & $-4.66^{*}$ & $-3.11^{*}$ & $-4.71^{*}$ & -1.64 \\
\hline Panel PP-statistic & $-3.32^{*}$ & $-4.45^{*}$ & $-2.64^{*}$ & $-4.54^{*}$ & -1.64 \\
\hline Panel & $-5.69^{*}$ & $-3.84^{*}$ & $-2.30^{*}$ & $-4.11^{*}$ & -1.64 \\
\hline ADF-statistic & & & & & \\
\hline \multicolumn{6}{|c|}{ Between Dimensions Group Statistics } \\
\hline Group p-statistic & -0.36 & $-3.22^{*}$ & $-2.13^{*}$ & $-3.22^{*}$ & -1.64 \\
\hline Group & $-2.16^{*}$ & $-4.44^{*}$ & $-2.45^{*}$ & $-4.44^{*}$ & -1.64 \\
\hline
\end{tabular}


$\begin{array}{llllll}\text { Group } & -5.98^{*} & -4.43^{*} & -3.04^{*} & -4.43^{*} & -1.64\end{array}$

Notes: (1) Model is estimated for $\mathrm{N}=24$ and $\mathrm{T}=37$; (2) All the reported values in the Pedroni tests are distributed as $\mathrm{N}(0,1)$ under the null hypothesis of a unit root or no cointegration. "Weighted" denotes that the panel statistics are weighted by the long-run variances. "Unweighted" denotes that the panel statistics are unweighted by the long-run variances; (3) * indicates the statistical significance and implied rejection of the null hypothesis.

Table 8: Sensitivity of the Maddala-Wu-Johansen rank tests for the long-run model.

\begin{tabular}{|c|c|c|c|c|c|c|c|c|}
\hline \multirow{3}{*}{$\begin{array}{l}\text { VAR } \\
\text { Lag, k }\end{array}$} & \multicolumn{8}{|c|}{$\mathrm{H}_{0}$ : No Cointegration; $\mathrm{H}_{1}$ : Cointegration } \\
\hline & \multicolumn{4}{|c|}{$\lambda$-trace Rank Test } & \multicolumn{4}{|c|}{$\lambda$-max Rank Test } \\
\hline & $\mathrm{H}_{0}$ & $\mathrm{H}_{1}$ & $\lambda$-trace & p-value & $\mathrm{H}_{0}$ & $\mathrm{H}_{1}$ & $\lambda-\max$ & $\mathrm{p}$-value \\
\hline \multirow[t]{2}{*}{1} & $r=0$ & $r \geq 1$ & $104.0^{*}$ & 0.0000 & $r=0$ & $r=1$ & $87.92^{*}$ & 0.0004 \\
\hline & $r \leq 1$ & $r=2$ & $82.35^{*}$ & 0.0015 & $r \leq 1$ & $\mathrm{r}=2$ & $82.35^{*}$ & 0.0015 \\
\hline \multirow[t]{2}{*}{2} & $r=0$ & $r \geq 1$ & $77.32^{*}$ & 0.0046 & $r=0$ & $r=1$ & $66.85^{* *}$ & 0.0372 \\
\hline & $r \leq 1$ & $r=2$ & $69.80^{* *}$ & 0.0216 & $r \leq 1$ & $r=2$ & $69.80^{* *}$ & 0.0216 \\
\hline \multirow[t]{2}{*}{3} & $\mathrm{r}=0$ & $r \geq 1$ & $93.18^{*}$ & 0.0001 & $r=0$ & $r=1$ & $87.53^{*}$ & 0.0004 \\
\hline & $r \leq 1$ & $r=2$ & $63.36^{* * *}$ & 0.0678 & $r \leq 1$ & $r=2$ & $63.36^{* * *}$ & 0.0678 \\
\hline \multirow[t]{2}{*}{5} & $r=0$ & $r \geq 1$ & $105.4^{*}$ & 0.0000 & $r=0$ & $r=1$ & $88.61^{*}$ & 0.0003 \\
\hline & $r \leq 1$ & $r=2$ & $77.09^{*}$ & 0.0049 & $r \leq 1$ & $r=2$ & $77.09^{*}$ & 0.0049 \\
\hline \multirow[t]{2}{*}{6} & $r=0$ & $r \geq 1$ & $147.4^{*}$ & 0.0000 & $\mathrm{r}=0$ & $r=1$ & $126.4^{*}$ & 0.0000 \\
\hline & $r \leq 1$ & $r=2$ & $97.82^{*}$ & 0.0000 & $r \leq 1$ & $r=2$ & $97.82^{*}$ & 0.0000 \\
\hline \multirow[t]{2}{*}{7} & $r=0$ & $r \geq 1$ & $183.6^{*}$ & 0.0000 & $r=0$ & $r=1$ & $167.9^{*}$ & 0.0000 \\
\hline & $r \leq 1$ & $r=2$ & $87.37^{*}$ & 0.0004 & $r \leq 1$ & $\mathrm{r}=2$ & $87.37^{*}$ & 0.0004 \\
\hline
\end{tabular}

Notes: (1) Model is estimated using an intercept (but no trend) term; (2) The p-values are based on MacKinnon, Haug, and Michelis (1999); (3)*,** and *** indicate the statistical significance and implied rejection of the null hypothesis at $1 \%, 5 \%$ and $10 \%$ levels, respectively; (4) $r$ denotes the number of cointegrating vectors.

\section{Notes}

${ }^{1}$ Husted (1992) also tests for cointegration between nominal trade flows deflated by nominal GNP and between real trade flows deflated by real GNP; where GNP denotes the gross national product. There is a remarkable similarity in regressions. The slope coefficients are similar in value, significantly below unity, while the constants tend to be imprecisely measured (Husted 1992).

${ }^{2}$ The Kao test (Kao 1999) is analogous to the Pedroni test (Pedroni, 1999, 2004), but it specifies cross-section specific intercepts and $\dddot{\varrho}$ homogenous coefficients in the first stage regression. The residuals from first stage regression, $y_{i t}=\alpha_{i}+\sum_{m=1}^{\mathrm{M}} \beta_{\mathrm{m} r} x_{\mathrm{mil}}+\varepsilon_{\mathrm{it}}$ are used to estimate the auxiliary regression, $\delta \varepsilon_{\mathrm{it}}=\rho \varepsilon_{\mathrm{it}-1}+\nu_{\mathrm{it}}$, or augmented auxiliary regression, $\delta \varepsilon_{\mathrm{it}}=\rho \varepsilon_{\mathrm{it}-1}+\sum_{\mathrm{i}=1}^{k} \xi_{\mathrm{f}} \delta \varepsilon_{\mathrm{it}-1}+\nu_{\mathrm{it}}$, to test $\mathrm{H}_{0}: \varepsilon(\mathrm{t}) \sim$ $I(1)$ against $\mathrm{H}_{1}: \varepsilon(\mathrm{t}) \sim I(0)$.

\section{References}

Arellano, M., and S. Bond. 1991. "Some Tests of Specification for Panel Data: Monte Carlo Evidence and an Application to Employment Equations." The Review of Economic Studies 58 (2): 277-297.

Arize, A.C 2002. "Imports and Exports in 50 Countries: Tests of Cointegration and Structural Breaks." International Review of Economics \& Finance 11 (1): 101-115.

Bajo-Rubio, O., C. Díaz-Roldán, and V. Esteve. 2014. "Sustainability of External Imbalances in the OECD Countries." Applied Economics, February 46 (4): 441-449.

Bergin, P.R., and S.M. Sheffrin. 2000. "Interest Rates, Exchange Rates and Present Value Models of the Current Account." The Economic Journal 110 (463): 535-558.

Breitung, ] 2002. "Nonparametric Tests for Unit Roots and Cointegration." Journal of Econometrics 108 (2): 343-363.

Camarero, M., J.L. Carrion-i-Silvestre, and C. Tamarit. 2013. "Clobal Imbalances and the Intertemporal External Budget Constraint: A Multicointegration Approach." Journal of Banking \& Finance 37 (12): 5357-5372.

Chen, S.-W., and Z. Xie. 2015. "Testing for Current Account Sustainability under Assumptions of Smooth Break and Nonlinearity." International Review of Economics \& Finance 38: 142-156.

Christopoulos, D., and M.A. León-Ledesma. 2010. "Current Account Sustainability in the US: What Did We Really Know about It?" Journal of International Money and Finance 29 (3): 442-459.

Chu, H.-P., T. Chang, H.-L. Chang, C.-W. Su, and Y. Yuan. 2007. "Mean Reversion in the Current Account of Forty-Eight African Countries: Evidence from the Panel SURADF Test." Physica A: Statistical Mechanics and Its Applications 384 (2): 485-492. 
Clarida, R.H., M. Goretti, and M.P. Taylor. 2007. "Are There Thresholds of Current Account Adjustment in the G7?.". In Clarida, R.H. (Ed.), G7 Current Account Imbalances: Sustainability and Adjustment. 169-204. Chicago: The University of Chicago Press Chapter 5.

Dickey, D.A., and W.A. Fuller. 1981. "Likelihood Ratio Statistics for Autoregressive Time Series with a Unit Root." Econometrica 49 (4): 1057-1072.

Durdu, C.B., E.C. Mendoza, and M.E. Terrones. 2013. "On the Solvency of Nations: Cross-Country Evidence on the Dynamics of External Adjustment." Journal of International Money and Finance 32: 762-780.

Edwards, S 2002. "Does the Current Account Matter?.". In Edwards, S., and J.A. Frankel (Eds.), Preventing Currency Crises in Emerging Markets. 21-69. USA: National Bureau of Economic Research, The University of Chicago Press January, Chapter 1.

Engle, R.F., and C.W.J. Granger. 1987. "Cointegration and Error Correction: Representation, Estimation, and Testing." Econometrica 55 (2): $251-276$.

Freund, C 2005. "Current Account Adjustment in Industrial Countries." Journal of International Money and Finance 24 (8): 1278-1298.

Hadri, K 2000. "Testing for Stationarity in Heterogeneous Panel Data." Econometrics Journal 3 (2): 148-161.

Hakkio, C.S., and M. Rush. 1991. "Is the Budget Deficit 'Too Large?'." Economic Inquiry 29 (3): 429-445.

Hansen, L.P 1982. "Large Sample Properties of Ceneralized Method of Moments Estimators." Econometrica 50 (4): 1029-1054

Hausman, J.A 1978. "Specification Tests in Econometrics." Econometrica 46 (6): 1251-1271.

Holmes, M.] 2006. "How Sustainable are OECD Current Account Balances in the Long Run?" The Manchester School 74 (5): 626-643.

Husted, S 1992. "The Emerging U.S. Current Account Deficit in the 1980s: A Cointegration Analysis." The Review of Economics and Statistics 74 (1): 159-166.

Im, K.S., M.H. Pesaran, and Y. Shin. 2003. "Testing for Unit Roots in Heterogeneous Panels." Journal of Econometrics 115 (1): 53-74.

Irandoust, M., and ]. Ericsson. 2004. "Are Imports and Exports Cointegrated? an International Comparison." Metroeconomica 55 (1): 49-64.

Johansen, S. 1991. "Estimation and Hypothesis Testing of Cointegration Vectors in Gaussian Vector Autoregressive Models." Econometrica 59 (6): $1551-1580$.

Kao, C1999. "Spurious Regression and Residual-Based Tests for Cointegration in Panel Data." Journal of Econometrics 90 (1): 1-44.

Kim, H., K.-Y. Oh, and C.-W. Jeong. 2005. "Panel Cointegration Results on International Capital Mobility in Asian Economies." Journal of International Money and Finance 24 (1): 71-82.

Konya, L 2009. "The Sustainability of the Current Account in the Czech Republic, Hungary and Slovenia." Empirical Economics 36 (2): $367-384$. Krugman, P.R 1988. "Sustainability and the Decline of the Dollar.". In Bryant, R.C., C. Holtham, and P. Hooper (Eds.), External Deficits and the Dollar: The Pit and the Pendulum. 82-99. Washington, D.C: The Brookings Institution Press.

Kwiatkowski, D., P.C.B. Phillips, P. Schmidt, and Y. Shin. 1992. "Testing the Null Hypothesis of Stationarity against the Alternative of a Unit Root: How Sure are We that Economic Time Series Have a Unit Root?" Journal of Econometrics 54 (1-3): 159-178.

Lanzafame, M 2014. "Current Account Sustainability in Advanced Economies." The Journal of International Trade \& Economic Development 23 (7): 1000-1017.

Levin, A., C.-F. Lin, and C.-S.J. Chu. 2002. "Unit Root Tests in Panel Data: Asymptotic and Finite-Sample Properties." Journal of Econometrics 108 (1): $1-24$.

Levy, D 2000. "Investment-Saving Comovement and Capital Mobility: Evidence from Century Long U.S. Time Series." Review of Economic Dynamics 3 (1): 100-136.

Liu, P.C., and E. Tanner. 1996. "International Intertemporal Solvency in Industrialized Countries: Evidence and Implications." Southern Economic Journal 62 (3): 739-749.

MacKinnon, J.C., A. Haug, and L. Michelis. 1999. "Numerical Distribution Functions of Likelihood Ratio Tests for Cointegration." Journal of Applied Econometrics 14 (5): 563-577.

Maddala, C.S., and S. Wu. 1999. "A Comparative Study of Unit Root Tests with Panel Data and A New Simple Test." Oxford Bulletin of Economics \&Statistics 61 (4): 631-652.

Mark, N.C., and D. Sul. 2003. "Cointegration Vector Estimation by Panel DOLS and Long-Run Money Demand." Oxford Bulletin of Economics and Statistics 65 (5): 655-680.

Matsubayashi, Y 2005. "Are US Current Account Deficits Unsustainable?: Testing for the Private and Government Intertemporal Budget Constraints." Japan and the World Economy 17 (2): 223-237.

Milesi-Ferretti, C.M., and A. Razin. 1996. "Current-Account Sustainability.". In Princeton Studies in International Finance. 81. Princeton, New Jersey: Princeton University October.

Obstfeld, M. (2012).NBER Working Paper No. 17877 Cambridge, MA: National Bureau of Economic Research Does the Current Account Still Matter?March.

Obstfeld, M., and K. Rogoff. 1996. Foundations of International Macroeconomics. Cambridge, MA: MIT Press.

Obstfeld, M., and K. Rogoff. 2007. "The Unsustainable U.S. Current Account Position Revisited.". In Clarida, R.H. (Ed.), G7 Current Account Imbalances: Sustainability and Adjustment. 339-376. Chicago: The University of Chicago Press Chapter 9.

Otto, G 1992. "Testing a Present-Value Model of the CurrentAccount: Evidence from US and Canadian Time Series." Journal of International Money and Finance 11 (5): 414-430.

Pedroni, P 1999. "Critical Values for Cointegration Tests in Heterogeneous Panels With Multiple Regressors." Oxford Bulletin of Economics $\delta$ Statistics 61 (4): 653-670.

Pedroni, P 2000. "Fully Modified OLS for Heterogeneous Cointegrated Panels.". In Baltagi, B.H., T.B. Fomby, and R.C. Hill (Eds.), Advances in Econometrics. Vol. 15, 93-130. Emerald.

Pedroni, P 2001. "Purchasing Power Parity Tests in Cointegrated Panels." The Review of Economics and Statistics 83 (4): 727-731.

Pedroni, P 2004. "Panel Cointegration: Asymptotic and Finite Sample Properties of Pooled Time Series Tests with an Application to the PPP Hypothesis." Econometric Theory 20 (3): 597-625.

Pedroni, P 2007. "Social Capital, Barriers to Production and Capital Shares: Implications for the Importance of Parameter Heterogeneity from a Nonstationary Panel Approach." Journal of Applied Econometrics 22 (2): 429-451. 
Pesaran, M.H., Y. Shin, and R.P. Smith. 1999. "Pooled Mean Group Estimation of Dynamic Heterogeneous Panels." Journal of the American Statistical Association 94 (446): 621-634.

Phillips, P.C.B., and B.E. Hansen. 1990. "Statistical Inference in Instrumental Variables Regression with I(1) Processes." The Review of Economic Studies 57 (189): 99-125.

Phillips, P.C.B., and P. Perron. 1988. "Testing for a Unit Root in Time Series Regression." Biometrikn 75 (2): 335-346.

Raybaudi, M., M. Sola, and F. Spagnolo. 2004. "Red Signals: Current Account Deficits and Sustainability." Economics Letters 84 (2): $217-223$.

Roubini, N., and P. Wachtel.. 1998. "Current Account Sustainability in Transition Economies.". In NBER Working Paper No. 6468. Cambridge, MA: National Bureau of Economic Research March.

Saikkonen, P 1991. "Asymptotically Efficient Estimation of Cointegration Regressions." Econometric Theory 7 (1): 1-21.

Sargan, J.D 1958. "The Estimation of Economic Relationships Using Instrumental Variables." Econometrica 26 (3): 393-415.

Sawada, Y 1994. "Are the Heavily Indebted Countries Solvent?: Tests of Intertemporal Borrowing Constraints." Journal of Development Economics 45 (2): $325-337$.

Stock, J.H., and M.W. Watson. 1993. "A Simple Estimator of Cointegrating Vectors in Higher Order Integrated Systems." Econometrica 61 (4): 783-820.

Swamy, P.A.V.B 1970. "Efficient Inference in a Random Coefficient Regression Model." Econometrica 38 (2): 311-323.

Taylor, A.M 2002. "A Century of Current Account Dynamics." Journal of International Money and Finance 21 (6): 725-748.

Trehan, B., and C.E. Walsh. 1991. "Testing Intertemporal Budget Constraints: Theory and Applications to U.S. Federal Budget and Current Account Deficits." Journal of Money, Credit and Banking 23 (2): 206-223.

Wickens, M.R., and M. Uctum. 1993. "The Sustainability of Current Account Deficits: A Test of the US Intertemporal Budget Constraint." Journal of Economic Dynamics and Control 17 (3): 423-441.

Wu, 3.-L 2000. "Mean Reversion of the Current Account: Evidence from the Panel Data Unit-Root Test." Economics Letters 66 (2): 215-222.

Wu, J.-L., S.-L. Chen, and H.-Y. Lee. 2001. "Are Current Account Deficits Sustainable? Evidence from Panel Cointegration." Economics Letters 72 (2): 219-224.

Wu, J.-L., S. Fountas, and S.-L. Chen. 1996. "Testing for the Sustainability of the Current Account Deficit in Two Industrial Countries." Economics Letters 52 (2): 193-198. 